\title{
Teaching descriptive-text writing through flannel doll for eight grade students of Junior High School
}

\author{
Anggraini Wulansari \\ Department of English Teaching, Universitas PGRI Madiun, Indonesia
}

\begin{tabular}{l}
\hline Article Info \\
\hline Article history: \\
Received January 18, 2019 \\
Revised March 22, 2019 \\
Accepted June 18, 2019 \\
\hline
\end{tabular}

Keywords:

writing;

teaching writing;

descriptive text;

flannel doll

\begin{abstract}
The purposes of this research are to describe the procedure and the strengths and weaknesses of teaching descriptive-text writing through flannel doll for eight grade students of SMPN 1 Maospati. The research uses qualitative as the approach. The design of this research is descriptive research. This research covers of eight grade students of SMPN 1 Maospati. The sample of the research is 30 students of $8 \mathrm{I}$ grade which consist of fifteen male and fifteen female. This sample is chosen by purposive sampling. The technique of analyzing data is compiling data, disassembling, reassembling, interpreting, and concluding. The result of the research are: (1) The procedure of "Teaching Descriptive-Text Writing through Flannel Doll for Eight Grade Students of SMPN 1 Maospati" consists of preparation and presentation done by the teacher. These preparation activities includes preparing the Syllabus, RPP, lesson plan, flannel doll, then preparing the classroom into five groups in break time. The presentation activities include pre-activities, whilst-activities, and post-activities. Pre-activities include greeting, checking attendance, and giving apperception and motivation by showing flannel doll. Whilst-activities include giving explanation (modeling) about descriptive text, joint construction of descriptive text about flannel doll (show how to planning and drafting with students), independent construction of descriptive text about each group' flannel doll (the steps are planning, drafting (writing), revising, editing, and final version (publishing). Postactivities include review and conclude the material. (2) The strengths are flannel doll make the students are enthusiastic, interested in English lesson, happy, active, enjoy, helpful, and easier in writing descriptive text, flannel doll increase the students' vocabulary and understanding in writing descriptive text, the using of flannel doll in descriptive text writing is suitable for eight grade students of SMPN 1 Maospati, guiding and explaining writing step and the using of editing and revising checklist is helpful for the students in writing descriptive text activity. While the weaknesses are the process of making six flannel dolls need more time, flannel doll will easily dirty if it is not in good hands, some students still crowded in the class, and some students confused to describe the unfamiliar color and the size of the doll's clothes.
\end{abstract}

Corresponding Author:

\section{Anggraini Wulansari}

Department of English Teaching, Faculty of Teacher Training and Education

Universitas PGRI Madiun

Jalan Setiabudi No.85 Madiun

Email: zy.gyra@gmail.com

\section{INTRODUCTION}

Language is important part in human's life. People use language to interact with other people or community. Language makes them understand each other. Language is tool that enable people to 
communicate and understand clearly what is other people thought with each other through vocal (speaking), written (written text/symbols), or gestures (Brown, 2000: 5). So it can be concluded that people can communicate using vocal, written, or gesture with other people.

Make written text is difficult for many students. Writing is a difficult skill to be mastered by first language learner, so it has more difficulties to be mastered by foreign language learner (Hadfield, 2011: 116) like Indonesian students. In real condition, the difficulties of writing are experienced by all students, including class 8I students of SMPN 1 Maospati. Ordinarily, the difficulties experienced by the students are in: starting their writing, arranging the word and sentences, organizing their ideas, punctuation, grammatical and linking one idea with others ideas. The cause that make the students difficult in writing is not only occurs from the students, but also from the teacher. The teachers usually give the students task to make writing without explaining to their students how to start their writing, the steps of writing it self, and after their students collecting their writing task, the teachers do not show the errors and how to correct the errors in their writing. The media that is used by the teacher in teaching writing also gives contribution for the students' difficulties in writing. The teachers usually use media that is conventionally used everyday such as text book, and whiteboard or blackboard. This conventional media make the students bored and do not have motivation in writing activity. It makes the students difficult to develop their writing skill.

In this case, the media that is suggested by the researcher is flannel doll. Flannel doll is children toy, puppet, or marionette that represents live in miniature (The Connecticut Doll Artist, 1995: 1) and made of colorful flannel cloth. Nowadays, doll from felt or flannel had a great vogue for all age, including students. They usually interested in the color, feature, materials, and the shape of the flannel doll that represent person, animals, or take other shape in miniature. Therefore, those features of flannel doll are useful and appropriate in teaching writing, especially teaching writing descriptive text. Moreover, it is easier to describe something that they can observe or touch than just imagines the thing. Because of its popularity, attractiveness and usefulness, flannel doll is appropriate to make the students giving their attention, more enthusiastic in writing activity, and they will be able to develop their writing skills. Based on the explanation above, the researchers intended to know not only the procedure, but also the strengths and weaknesses of "Teaching DescriptiveText Writing through Flannel Doll for Eight Grade Students of SMPN 1 Maospati.

\section{RESEARCH METHOD}

This research is done in 9th May 2014 in SMPN 1 Maospati in the schooling year 2013/2014. This school is located at Jl. Prawirodirjo Kel. Kraton, Kec. Maospati. Kab. Magetan. The design of this research uses Descriptive Qualitative. In descriptive research design, the research makes a rich description about phenomena, events, or behavior of subject under study from data form of word, pictures which is collected from observation, interview, and documentation to understanding and describing how to teach descriptivetext writing through flannel doll for eight grade students of SMPN 1 Maospati and the strengths and weaknesses.

The population is 300 grade eight students of SMPN 1 Maospati in the schooling year of 2013/2014. The participant is 30 of $8 \mathrm{I}$ students consist of 15 male and 15 female. This class is selected by purposive sampling because this class is really active, but need different learning atmosphere that make them learning with fun especially in writing activity. Here the researcher collecting the data by observing the teaching and learning process, here the researcher choose role as participant as observer that helped by two rater, they are the researcher's friend and the English teacher of class 8I, interviewing the teacher and the students, and take photographs and documents of teaching and learning process.

The researcher uses investigator triangulation (more than one observer) and methodological triangulation (more than one data collecting technique) as the validating techniques. The analysis of data is done first through compiling the data. The data that is collected is students' pre-interview, teacher's pre interview, then observing and collecting the document in the teaching and writing descriptive text process through flannel doll, and the last is interviewing the students and the teacher after teaching and learning process. Second, the researcher disassembles the data one by one of each data and choosing the appropriate 
data needed in the research. Third is the researcher transcribing and reassembling the raw data in order and put the photographs in the right order to help the researcher in the next step, it is interpreting the data. Then the researcher concludes how to teach descriptive-text writing through flannel doll in eight grade students of SMPN 1 MAOSPATI in the schooling year of 2013/2014, and its strengths and weaknesses to answer the research problems and make suggestions.

\section{RESULTS AND DISCUSSION}

The result of observation, photographs, and interview is explained from preparation and teaching and learning process. In preparation, the teacher prepares the classroom by dividing the students into five groups consist of six students. Then, in teaching and learning process, the teacher used three steps. They were pre-activities, while-activities, and post-activities.

1. Pre Activities: a) the teacher's activities were greeting, b) checking the students' attendance and the result is the students was complete, and c) giving apperception and motivation by showing flannel doll shaped of Indian tribe to the students and in this session the students stimulated, motivated and interested in flannel doll and enthusiastic in giving their opinion and some questions about the doll.

2. Whilst-Activities: a) Explanation (Modeling) briefly about descriptive text and writing steps to developing the students background knowledge in the lesson. b) Joint Construction of Text, teacher show and explained to the students how to start (planning) and developing descriptive text (drafting) about Indian tribe doll. Here the students gave their contribution by giving their ideas in planning and drafting. c) Independent Construction of Text. The volunteer of each groups make a line and choose one flannel doll from box. The students look happy and interested when they got the doll. Then the teacher asked the students to observing and planning the descriptive text about the doll, here the teacher help some students who need help such as confused with the unfamiliar color and size of the doll's cloth especially Little Girl Doll. Then the teacher asked the students to make draft, then the teacher show to the students how to revise and edit the draft using revising and editing checklist, next the teacher asked the students to revise, and edit the draft using revising and editing checklist, then copy the final version in the last box neatly. In the final version some students decorated their final version. The last instruction from the teacher is to analyzing their own writing according to the organization of descriptive text.

3. Post-Activity: a) the teacher reviews the material, conclude the material, and close the meeting. Here the students showed that they have more understanding about descriptive text and how to make descriptive text.

The result of students' and teacher's pre-interview, and students' and teacher's post interview can be showed as follows: The students' likeness in English lesson is increase. In pre interview there were 5 students like English, 3 students not too much like English, 2 students do not like English. While in the post interview showed that 10 students felt happy, enjoy, interested, and have more understanding in teaching English using flannel doll the students do not felt bored, so they felt easy and helpful in learning English. The students who feel difficult in writing. In pre interview there are 2 students feel that writing in English is difficult, 3 Students feel that writing in English is difficult enough, 5 Students feel that writing in English is not too difficult. Then in post interview 10 students feel helpful and easier in writing after using flannel doll. 2 students feel confuse with the color and the size of the doll's cloths, and 8 students feel that flannel doll have no weaknesses. 2 students suggest makes bigger doll, 1 student suggest makes more interesting doll, and 7 students have no suggestion about the doll. 10 students feel that they have more understanding after the teacher explain how to arrange descriptive text together. 10 students feel helpful, more understand, and easier in arranging descriptive text after knowing the writing steps. 10 students have more understanding how to make descriptive text correctly after using checklist. Research finding from the teacher's interview. The teacher have never used flannel doll before, usually the teacher just give the students task to describe their house, or when in school the teacher asks them to describe picture in the projector. The students give good response, the students looks happy, motivated, enthusiastic, active, and enjoy to describe the flannel doll. The using of flannel doll in teaching writing descriptive text is suitable used in the school. The strengths of 
media flannel dolls are cute, colorful, it can be seen by the students directly, so they did not need to imagine the thing they want to describe, it is helpful and make them interested in describing something. The weaknesses are a) the process of making six flannel dolls need more time, b) flannel doll will easily dirty and damage if it is not in good hands, c) some students still crowded in the class. The teacher's suggestion to optimize flannel doll as the media are: 1) In helping the teacher in making the doll so it will not need much time, the teacher can just make one doll for one class, then put the doll in the center of the class. 2) To make the flannel doll does not easily dirty, had better to cover the doll in a mica box, so the flannel clothes and the color durable, clean, do not easily damaged. With this method, the students can observe and describe the doll without damage the doll. By the using of flannel doll the students have more enthusiastic in learning English, know how to start and organize their writing, and they can learn to find new vocabularies when they observe the flannel doll in their dictionary. Guiding and explaining the steps of writing to the students is helpful for the students in completing writing task.

Preparation: the teacher design writing activity especially for classroom activity which supports the students to pass the process of writing through classroom preparation by asking the students to make six groups contains of five students before the class was begun exactly in the break time. Teacher's activity above is supported by Hedge (2008: 13), "Students need time in the classroom for writing. The teacher's task is to select or design activities which support them through the process of producing a piece of writing." PreActivities: (1) the teacher's activities were greeting, (2) checking the students' attendance and the result is the students was complete, and (3) giving apperception and motivation by showing flannel doll shaped of Indian tribe to the students and in this session the students stimulated, motivated and interested in flannel doll and enthusiastic in giving their opinion and some questions about the doll. Whilst-Activities: (1) Explanation (Modeling) briefly about descriptive text and writing steps to developing the students background knowledge in the lesson. This step is done based on Firkins, Forey, and Sengupta (2007: 7). (2) Joint Construction of Text, teacher show and explained to the students how to start (planning) and developing descriptive text (drafting) about Indian tribe doll. This activity is done based on Firkins (2007: 7). Here the students gave their contribution by giving their ideas in planning and drafting. (3) Independent Construction of Text. The volunteer of each groups make a line and choose one flannel doll from box. The students look happy and interested when they got the doll. Then the teacher asked the students to observing and planning the descriptive text about the doll, here the teacher help some students who need help such as confused with the unfamiliar color and size of the doll's cloth especially Little Girl Doll. Then the teacher asked the students to make draft, then the teacher show to the students how to revise and edit the draft using revising and editing checklist, next the teacher asked the students to revise, and edit the draft using revising and editing checklist, then copy the final version in the last box neatly. In the final version some students decorated their final version. The last instruction from the teacher is to analyzing their own writing according to the organization of descriptive text. The teaching learning cycle is done based on Rothery in Firkins, Forey and Sengupta (2007: 7). While the writing steps is done according to Harmer (2004: 4-5) and Nunan (2005: 107-108) . Post-Activity: a) the teacher reviews the material, giving some question to check the students understanding, conclude the material, and close the meeting.

The students gave good response and become enthusiastic and interested in English lesson. It is showed when the students active in giving their opinion and asking about Indian Flannel Doll. Then from the photographs it can be seen when the students look happy got Flannel Doll from the teacher. Then from 10 students interviewed, showed that the students' happiness increase from 5 to 10 students and the teacher stated that the students give good response in teaching and learning process. The students were happy, active, enjoy, helpful, and easier in writing descriptive text using flannel doll. It showed when the students looked happy in observing and animating the doll while planning and drafting. Then from the documents it shows in the students' descriptive text writing. The students pass the five steps of writing they are planning, drafting, revising, editing, and make the final version. While from the interview, it is proved when 10 students stated that they are easier in write descriptive text using flannel doll. The using of flannel doll in teaching writing descriptive text is suitable used in SMPN 1 Maospati. It is showed in the teacher's interview

English Teaching Journal, Vol. 7, No. 1, June 2019: 9-14 
that the using of flannel doll is suitable in the school. Guiding and explaining the steps of writing descriptive text using flannel doll are helpful for the students in writing task. It is showed when 10 students interviewed answers that it is easier when the students explaining and guiding how to make descriptive text using doll and writing steps. The students feel have more understanding how to writing descriptive text correctly using editing revising and checklist. It is showed when 10 students interviewed stated that it is easier to revise and edit using revising and editing checklist. While from the students' descriptive text writing, there are some students who revise the title and content of their writing according to the revising and editing checklist. By using flannel doll the students know how to start and organize the writing, and the students can learn to find new vocabularies when the students observe the flannel doll in the dictionary. It is showed when the students make planning and drafting, they open their dictionary to find the new vocabulary to describe the flannel doll. Then it showed too from the result of the teacher's post interview. The process of making six flannel dolls needs a lot of time. It is showed in the result of photographs. The teacher need to cut the pattern of the body, clothes, and accessories, sew and fill with Dacron, and joint all parts of the flannel doll. Flannel doll will be easily dirty if it is not in good hands. It is showed when the students observing and animating the doll, it makes the doll a little damage and dirty. So the teacher needs to maintain the doll. Some students are still crowded in the class. It is supported from the teacher's interview that there are some students crowded. While from the photographs it is showed when some students want to see the other groups' Flannel doll. Some students are confused with unfamiliar color and size of the doll's clothes. It s showed from the observation when some students from Little Girl Doll's group ask the teacher's opinion about the cloths color and the size of the doll's cloths. Beside that it is showed from the students interview that some of them confused about the color and the size of the doll's cloths.

\section{CONCLUSION}

The procedure of teaching descriptive-text writing through flannel doll for eight grade students of SMPN 1 Maospati in the schooling year of 2013/2014. Preparation activities includes preparing the Syllabus, RPP, lesson plan, media (flannel doll), then preparing the classroom into five group in break time. The presentation activities include pre-activities, whilst-activities, and post-activities. Pre-activities include greeting, checking attendance, and giving apperception and motivation by showing flannel doll. Whilstactivities include giving explanation (modeling) about descriptive text, joint construction of descriptive text about flannel doll (show how to planning and drafting with students), independent construction of descriptive text about each group's flannel doll (the steps are planning, drafting (writing), revising, editing, and final version (publishing). Post-activities include review and conclude the material. The procedure is done based on Teaching Learning Cycle of Rothery in Firkins, Forey and Sengupta (2007: 7) and the writing steps is done according to Harmer (2004: 4-5) and Nunan (2005: 107-108).

The strengths of teaching descriptive-text writing through flannel doll for eight grade students of SMPN 1 MAOSPATI in the schooling year of 2013/2014. The strengths are: a) The students give good response and more enthusiastic and interested in English lesson. b) Flannel doll make the students happy, active, enjoy, helpful, and easier in writing descriptive text. c) Flannel doll increasing the students' vocabulary. d) The using of flannel doll in teaching writing descriptive text is suitable used in the school. e) Guiding and explaining the steps of writing using flannel doll are helpful for the students in completing writing task. f) The using of revising and editing checklist help the students in writing. The weaknesses are: a) Process of making six flannel dolls need a lot of time. b) Flannel doll will be easily dirty and damage if it is not in good hands. c) Some students are still crowded in the class. d) Some students are confused with unfamiliar color and size of the doll's clothes.

Based on the result of the research about "Teaching Descriptive-Text Writing through Flannel Doll for Eight Grade Students of SMPN 1 MAOSPATI in the Schooling Year of 2013/2014" the researcher hopes that the readers uses Flannel doll in teaching descriptive-text writing. Because it can make teaching learning not boring and students become more interested, and enjoy in the following teaching learning process. The students are suggested to pay attention, active and do not give up in learning English and brave to asking help to the teacher if they find difficulties. Then the teacher is suggested to use various kinds of traditional and 
electronic media alternately in the teaching learning process. While for the other researcher is suggested to create new media, game or technique for the educational beneficial.

\section{REFERENCES}

Brown, H. D. (2000). Principles of Language Learning and Teaching (4th ed.). New York: Addison Wisley Longman, Inc.

Hadfield, J. \& Hadfield, C. (2011). Introduction to Teaching English. New York: Oxford University Press.

Lemlech, J. K. (2010). Curriculum and Instructional Methods for the Elementary and Middle School (7th ed.). Boston: Allyn and Bacon.

Broughton, G., Brumfit, C., Flavell, R., Hill, P., \& Pincas, A. (2003). Teaching English as a Foreign Language (2nd ed.). New York: Routledge.

Harmer, J. (2004). How to Teach Writing. England: Pearson Education Limited.

Hyland, K. (2004). Second Language Writing. New York: AltaMira Press.

Nunan, D. (Ed.) \& Linse, C.T. (2005). Practical English Language Teaching: Young Learner. New York: The McGraw-Hill Companies, Inc.

Pardiyono. (2007). Pasti Bisa! Teaching Genre-Based Writing. Yogyakarta: Andi.

Lee, D. WY. (2001). Genres, Register, Text Types, Domains, And Styles: Clarifying the Concepts and Navigating a Path through the BNC Jungle. Language Learning \& Technology, 5, 37-72.

Anderson, M. and Anderson, K. (2003). Text Types in English. Australia: Macmillan.

The Connecticut Doll Artist. (1995). Doll FAQs, (Online), (http://ctdollartists.com/history.htm, Accessed on April, 2nd 2014).

Thornton, S. (2010). Cloth Settlers: Fine Art Dolls Populating the Textile Art Landscape. Textile Society of America Symposium Proceedings. Paper 66.

Smithsonian Institution. (2004). Smithsonian in Your Classroom. Smithsonian Institution, (Restricted from http://smithsonianeducation.org/images/educators/lesson_plan/native_dolls/native_dolls.pdf, Downloaded on April, 2nd 2014)

Ollerenshaw, India. (2002). Medieval Dolls. Aelflaed of the Weald, (online), (http://aelflaed.homemail.com.au/doco/dolls.html, Accessed on April, $2^{\text {nd }}$ 2014).

Treasure, S.R. (2011). The Vintage Cloth Dolls Of Gre-Proir Inc., (Online), (http://ezinearticles.com/?TheVintage-Cloth-Dolls-Of-Gre-Proir-Inc\&id=6331651, Accessed on April, 1st 2014).

Sewing and Craft Alliance (S\&CA). (2008). SEW-lutions Guidelines: Your Guide to Successful Sewing. (Restricted from http://www.sewing.org/files/guidelines/4_120_napped_fabrics.pdf. Downloaded on Thursday, 26 December, 2013, 9:39 p.m.).

Hedge, T. (2008). Writing (2nd ed.). New York: Oxford University Press.Firkins, A., Forey, G., \& Sengupta, S. (2007). A Genre-Based Literacy Pedagogy: Teaching Writing to Low Proficiency EFL Students. English Language Teaching Journal 